The University of Southern Mississippi

The Aquila Digital Community

Faculty Publications

$7-1-2003$

\title{
Patterns of Elite Faunal Utilization in Moundville, Alabama
}

H. Edwin Jackson

University of Southern Mississippi, Ed.Jackson@usm.edu

Susan L. Scott

University of Southern Mississippi

Follow this and additional works at: https://aquila.usm.edu/fac_pubs

Part of the Anthropology Commons

\section{Recommended Citation}

Jackson, H. E., Scott, S. L. (2003). Patterns of Elite Faunal Utilization in Moundville, Alabama. American Antiquity, 68(3), 552-572.

Available at: https://aquila.usm.edu/fac_pubs/8247

This Article is brought to you for free and open access by The Aquila Digital Community. It has been accepted for inclusion in Faculty Publications by an authorized administrator of The Aquila Digital Community. For more information, please contact Joshua.Cromwell@usm.edu. 


\title{
PATTERNS OF ELITE FAUNAL UTILIZATION AT MOUNDVILLE, ALABAMA
}

\author{
H. Edwin Jackson and Susan L. Scott
}

\begin{abstract}
In recent years, zooarchaeological research has begun to examine the roles of animals as part of the suite of symbols employed in the ongoing social, ceremonial, and political dynamics of prehistoric cultural systems. In the southeastern United States, studies of late prehistoric Mississippian chiefdoms have documented differences in species composition and meat cuts associated with particular social contexts of consumption-for instance, ceremonial feasting vs. private meals-and also with gross distinctions in social rank-elite vs. commoner. Differences in the latter reflect elite control of procurement as well as cultural rules that assign meanings to certain species, which in so doing regulates access to their consumption. Faunal samples collected by recent mound excavations at the Moundville site in west-central Alabama provide the basis for an examination of more subtle differences in the consumption patterns of elite residents. Zooarchaeological samples produced by two elite households, although generally similar and fitting expectations for elite consumption well, are distinguished by differences in the distribution of rare species, the role of fish, and possibly by evidence of differences in food waste, distinctions that can be associated with interpretations of these households' relative status in Moundville society drawn from other classes of archaeological data.
\end{abstract}

En años recientes, la investigación zooarqueológica ha comenzado a examinar las funciones de los animales dentro de la dinámica del contexto social, ceremonial y político como parte de una serie de símbolos empleados continuamente en los sistemas culturales prehistóricos. En el sureste de los Estados Unidos, estudios sobre los asentamientos del período prehistórico tardio de la cultura Mississippi, han documentado diferencias en la composición de especies y cortes de carne asociadas con contextos sociales particulares de consumo alimenticio (por ejemplo, diferencias entre festines ceremoniales y comidas domésticas) y también con grandes diferencias en el estrato social (por ejemplo, entre la élite y los plebeyos). Las diferencias entre este último reflejan el control de la élite sobre las compras así como en las normas culturales relacionadas con el significado de ciertas especies y que al hacerlo, regulan el acceso al consumo. En excavaciones recientes llevadas a cabo en el sitio arqueológico de Moundville, localizado en la zona centro occidental del estado de Alabama, se han recogido muestras de fauna que proveen la base para un análisis de diferencias más sutiles en los patrones del consumo alimenticio de la élite. A pesar de algunas semejanzas generales y que encajan bien dentro de las expectativas del consumo de la élite, las muestras zooarqueológicas excavadas en dos viviendas pertenecientes a ese contexto se distinguen por las diferencias en la distribución de especies raras, la función del pescado y la evidencia de desperdicios de comida o métodos alternos para la preparación de alimentos. Estas distinciones pueden estar asociadas con las interpretaciones del estrato social de los habitantes de estas viviendas en Moundville, que han sido formuladas en base a otros tipos de datos arqueológicos.

I

n recent years anthropological research, both ethnographic and archaeological, increasingly has turned its attention to the social, political, and symbolic underpinnings of food practices in small-scale societies (Clarke and Blake 1994; Dietler 1996; Dietler and Hayden 2001; Hayden 1995, 1996; Knight 2001b; Potter 2000; Wiessner and Schiefenhovel 1996). Among the archaeological contributions to this discussion has been the demonstration of some of the ways in which food remains reflect social distinctions in prehistoric societies, particularly among those ranked middlerange societies, chiefdoms. Studies focusing on Mississippian chiefdoms of the southeastern United States have demonstrated the important role of feasting in political and ritual events (Blitz 1993b; Kelly 2001; VanDerwarker 1999) and the nature of economic relations between elite and commoner

H. Edwin Jackson and Susan L. Scott $\square$ Department of Anthropology and Sociology, University of Southern Mississippi, Hattiesburg, MS 39406-5074 
(Jackson and Scott 1995a; Scott 1983; Welch 1991; Welch and Scarry 1995). They have also begun to delineate how differences in access to particular foods and taxa provided an important symbolic medium for distinguishing the Mississippian elite from the rest of society (Bogan 1980; Jackson and Scott 1995b; Maxham 2000; Rees 1997; Scott and Jackson 1998; Welch 1991; Welch and Scarry 1995). Our analysis of faunal samples from Moundville elite contexts has been guided by previous work building on Scott's (1983) analysis of Mississippian faunal remains from the Lubbub Creek Archaeological Locality. Lubbub Creek is a single mound and village site that served as the civic and ceremonial center of a simple chiefdom occupying a stretch of the Tombigbee River in west-central Alabama, about $65 \mathrm{~km}$ from Moundville (Blitz 1993a).

Previous studies demonstrated distinctions in subsistence patterns at a fairly gross scale: urban vs. rural, elite vs. commoner. In this paper, we report on fauna recovered by excavations of mound summit and slope midden contexts at Moundville in Alabama, conducted by the University of Alabama between 1989 and 1998 under the direction of Vernon J. Knight. These data provide an opportunity not only to test some previous predictions regarding Mississippian elite animal use patterns (Jackson and Scott 1995b; see below), but also to examine how the faunal record may indicate differences in the relative rankings of social units comprising the Moundville elite.

Moundville was the paramount center of a Mississippian polity on the Black Warrior River in west-central Alabama from roughly A.D. 1050 to 1450. During this interval the Moundville chiefdom was among the most centralized and complex chiefdoms to have developed in the southeastern U.S. It has been the subject of investigations for more than a century, resulting in an extraordinarily good understanding of the historical trajectory and organizational aspects of this important Mississippian chiefdom. We and other investigators (e.g., Knight 1995; Peebles 1983) are confident in interpreting mound-related refuse contexts as the product of elite domestic or ritual activity. Further, both Knight (1998) and Peebles $(1971,1978,1983)$ interpret differences in location, mound size, and artifact associations as reflecting differences in corporate group affiliation and status, as well as differences in mound function. The excavation of mound summit and slope refuse deposits (Knight 1995, 2001a; Markin 1997) has provided a host of data related to elite activity, including good evidence for elite faunal use.

\section{Expectations of Faunal Use among Mississippian Elite}

Social and political inequality and their expression in Mississippian economy, religious authority, and the symbolic system that sustained this system of relationships, conditioned access to meat and certain other animal products (Jackson and Scott 1995b). This is not surprising since meat is often accorded high social and symbolic value, particularly among groups that depend on hunting to obtain it (e.g., Kent 1989), and animals are commonly used to portray power, dominion, and a host of other characteristics that might be associated with leadership positions (Hudson 1976:128-130). Nutritional characteristics (e.g., fat content), cultural perceptions of meat quality (e.g., stringiness, taste), and culturally defined proscriptions might find themselves expressed as socially determined differences in access to certain cuts or taxa. We would expect differences in animal resource use to be a product of both the manner in which social difference is symbolized by foodways and the elites' access to labor and its effect on the mix of subsistence commodities. For instance, part of this variability may relate to the economic mechanisms by which the elite were provided with animal products. The distinctive nature of elite refuse would depend in part on the degree to which elite families relied on the efforts of their followers for food, through gifts, tribute, or systematic provisioning. With greater or more regular levels of subsistence provisioning, transport considerations might be expected to come into play (e.g., Welch and Scarry 1995), shifting the focus of hunting efforts to larger animals (Speth and Scott 1989), and increasing the likelihood and extent of field butchery. Under such conditions, elite households are predicted to have received field-dressed carcasses or solely the most desirable cuts. If the latter were the case, then hunters retained less valued portions of the prey. Thus, in contrast to the refuse that accumulated in non-elite contexts, elite bone accumulations generally can be expected to include a higher proportion of meat-bearing anatomical units and greater 
representation of the highest-quality cuts (Jackson and Scott 1995b). Mississippian period sites with evidence for distinctive elite patterns of faunal use include Cahokia in Illinois (Kelly 2001), Crenshaw in southwest Arkansas (Scott and Jackson 1998), Toqua in Tennessee (Bogan 1980; VanDerwarker 1999), and Lubbub Creek in west-central Alabama (Jackson and Scott 1995a; Scott 1983).

Different patterns of food preparation may also distinguish elite households from those of their followers. Greater tendency to roast rather than stew meat implies an abundance of available meat and could even serve as a sign of conspicuous waste; roasting results in the loss of drippings, and is more likely to emphasize the meatiest cuts. The alternative, stewing, is a more effective way to make complete use of prey, by stretching quantities with the addition of more water and including the meat on irregularly shaped elements, for instance vertebrae. If we can assume that in non-elite households complete carcass use was an overriding goal, then we would expect greater reliance on stewing for its efficient use of meat rather than on roasting and its attendant wastefulness. More intensive bone processing (smashing to gain access to marrow or boiling to render grease) may distinguish preparation activities in non-elite contexts, although this distinction could be mitigated by a high cultural value placed on marrow and grease. Marrow extraction, requiring just a single break, may well be equivalent in households of varying status. However, we suggest that the greater processing intensity required to render grease (extensive bone breakage plus boiling) is less likely to occur in high-status households with the same frequency found elsewhere, resulting in a smaller proportion of very fragmentary bone. It should be possible to gauge the effective utilization of bone products or, alternatively, wasteful behavior, by the relative degree of bone fragmentation exhibited by bone samples from different contexts.

Mississippian elite refuse appears to include a higher proportion of birds than are found in nonelite contexts, although the importance of birds varies significantly among Mississippian societies, and turkey in particular was staple fare in the diets of most Mississippians. Other taxa have more variable distributions that in at least some cases seem to be a function of differences in social status. For instance, at the Crenshaw site in southwest
Arkansas, samples from within an elite early Caddoan structure produced more than 90 percent of the excavated passenger pigeon remains. In contrast, turkey remains were nearly evenly split between elite structure samples and presumed nonelite contexts elsewhere on the site (Scott and Jackson 1998). The pattern suggests that passenger pigeon was a delicacy reserved for the elite.

To this point we have considered meat primarily as a commodity. However, we know from ethnohistoric accounts that certain animals were considered to represent or have qualities emanating from their place in the cosmological system of southeastern Indians (Hudson 1976:128-134). That the symbolic importance of sometimes mythical and sometimes real animals had roots in the prehistoric past is indicated by their ample depictions in Southeastern Ceremonial Complex (SECC) iconography (e.g., Galloway 1989). Since SECC iconography served to display the sanctity and power of the Mississippian elite, the extension of animal symbolism to acts of consumption is not such a far reach. In this way, meat consumption offers a potentially important mechanism for gaining or increasing desirable qualities, and in cultural contexts wherein asymmetric power relations dictate dietary choice, restrictions limiting that consumption only to those in power may help to explain variation in species representation.

Faunal samples representing elite contexts often include a broader range of uncommonly recovered taxa. Moreover, ethnohistoric accounts indicate that specific characteristics of certain animals were transferable by consumption of their meat (Jackson and Scott 1995b). While in some cases rare taxa simply may be delicacies, very often it is the qualities assigned to particular species that appear to promote their representation. An example is the greater representation of "dangerous" taxa, such as bear, cougar, or bobcat, implying consumption to obtain their power. Carnivores in particular are interesting inclusions in elite middens, since historically, at least, southeastern Indians considered flesh-eating animals taboo (Hudson 1976:318).

Birds, especially raptors such as hawks, owls, falcons, and eagles, are prominent in southeastern Indian cosmology as well as in Mississippian iconography, representing another category of "charged" taxa, with political as well as religious connotations. The distribution of these taxa is vari- 
ably restrictive. Eagles, for instance, while not common, are found in non-elite contexts. In contrast, the remains of peregrine falcons, often depicted in SECC iconography as a falcon warrior (Galloway 1989), have an extremely limited distribution in Mississippian sites and seem to be restricted to mound centers, such as Cahokia (Chmurny 1973; Kelly 2001) or Etowah (van der Schalie and Parmalee 1960). A large number of swans, a taxon that is generally rare in American Bottoms assemblages, was identified by Kelly (2001; also Pauketat et al. 2002) in feasting and ritual refuse found below Mound 51 at Cahokia. No wing elements were identified, suggesting that these had been made into fans and ultimately disposed of elsewhere (Kelly 2001:349). The data suggest that in addition to the meat provided by this large bird, associated symbolic meaning or prescribed ritual use may underlie its extraordinary frequency. Smaller birds, such as crows, jays, and other songbirds, though probably not important for their contribution to elite meals, nonetheless provide colored plumage that can often be related to color symbolism such as that associated with the cardinal directions, or war and peace. At Lubbub Creek, birds limited to mound contexts include cardinal, mockingbird, Carolina parakeet, crow, bluejay, and a merlin (Scott 1983).

The result is that in addition to greater-thanexpected large mammal meat-bearing elements, elite contexts are distinguished by more diverse assemblages that result from the preferential or exclusive access to certain species. However, a number of factors confound such a simple picture. First, we should not expect perfect uniformity throughout the Mississippian world in how or which animals symbolized ideological constructs or status differences. Second, meals may not be the only source of bone refuse; craft or paraphernalia manufacture that used animal parts, or animal remains resulting from ritual activities, may also contribute to the elite faunal record. Further, elite private refuse often may be mixed with the remains of ceremonial activities such as feasting (Pauketat et al. 2002:273-275). Where the economic organization provided daily fare to the elite, these same mechanisms likely also served to provision ceremonial feasts, so that it may be difficult to differentiate these sources of refuse when there is spatial overlap. If depositional events can be distinguished, feast provisioning should be reflected by very high proportions of large mammal remains, a function of maximizing the amount of meat available for the event, rather than by diverse assemblages (e.g., VanDerwarker 1999:26). However, a high diversity "pot luck" approach to supplying feasts also has been suggested (VanDerwarker 1999; Zeder 1996), in which multiple participants provide food. For instance, according to Charlevoix (Swanton 1911:122): "Each private person contributes something of his hunting, his fishing, and his other provisions, which consist in maize, beans, and melons" to the midsummer harvest festival held by the Natchez. Very large quantities of food refuse may be key to recognizing feasting episodes (e.g., Kelly 2001).

Finally, and this point takes on importance for understanding the present Moundville case, Mississippian chiefdoms were quite variable in their scale and degree of centralization. Mississippian polities ranged from apparent "big man" systems (e.g., Lorenz 1996) to complex or paramount chiefdoms, such as Cahokia or Moundville, with considerable variation in scale or centralized authority in between. Limitations on distribution of certain taxa, as well as the degree to which foodstuffs were mobilized to support ceremony or social group, are partly a function of degree of political centralization. This is itself a dynamic feature of Mississippian polities (e.g., Anderson 1994). We can assume a waxing of the political power of the Moundville elite during the period in which they mobilized the labor necessary to undertake the massive scale of mound and palisade construction in evidence at the site. This period might also represent a time of more regimented organization in the provisioning of Moundville elite, requiring more intensive exploitation of available faunal resources, than may have occurred either before or after, or than may have characterized smaller, less complex polities.

\section{Background to the Present Study}

\section{The Moundville Chiefdom}

Between approximately A.D. 1150 and 1500, Moundville served as the political and ceremonial center of a complex chiefdom in the Black Warrior River valley in Alabama (Figure 1). At its zenith the site covered 75 ha, included at least 29 earthen mounds, and was surrounded by a bastioned palisade early in its history (Knight and Steponaitis 


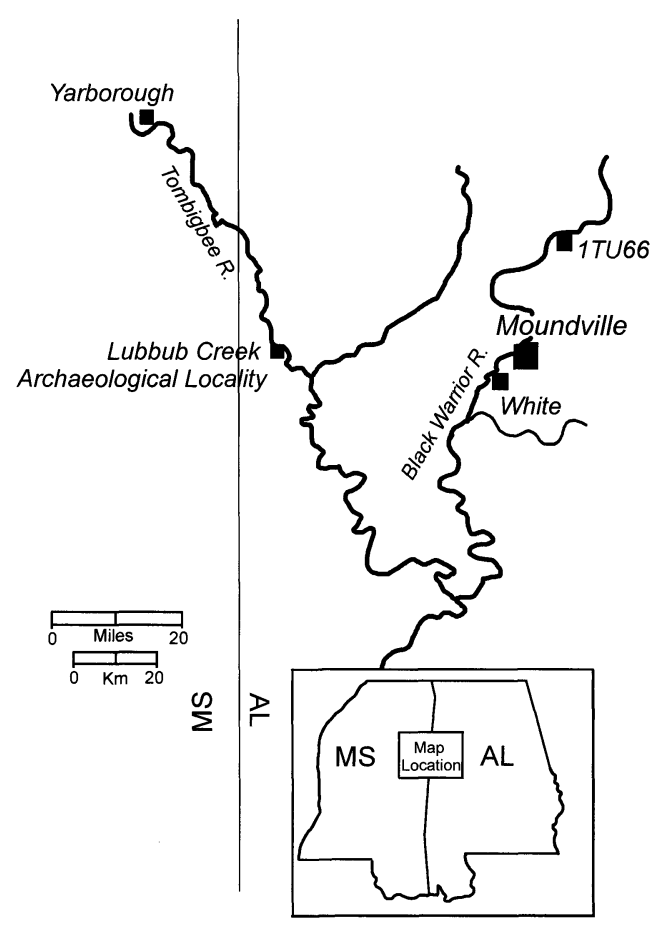

Figure 1. Location of Moundville and other sites mentioned in text.

1998) (Figure 2). Based on ceramic evidence, four chronological phases have been distinguished, Moundville I through IV (Figure 3). In the preceding Late Woodland West Jefferson phase, prior to A.D. 1050, occupation of the Black Warrior valley consisted of a series of nucleated settlements. Moundville's initial occupation began early in the Moundville I phase, represented by a single small mound and evidence of a small but growing resident population. Late in the Moundville I phase, between A.D. 1200 and 1250, population increased substantially, the plaza area was made level by the addition of fill in low areas, and work began on all the major mounds, providing the site with the spatial configuration depicted in Figure 2 (Knight and Steponaitis 1998:15). A palisade that encircled the mound group and associated residential area was constructed at this time, undergoing several rebuilding episodes in the thirteenth century. The resident population peaked during this interval, estimated to have been approximately 1,000, all living within the confines of the palisade. Several outlying secondary mound centers were established during the late Moundville I phase.

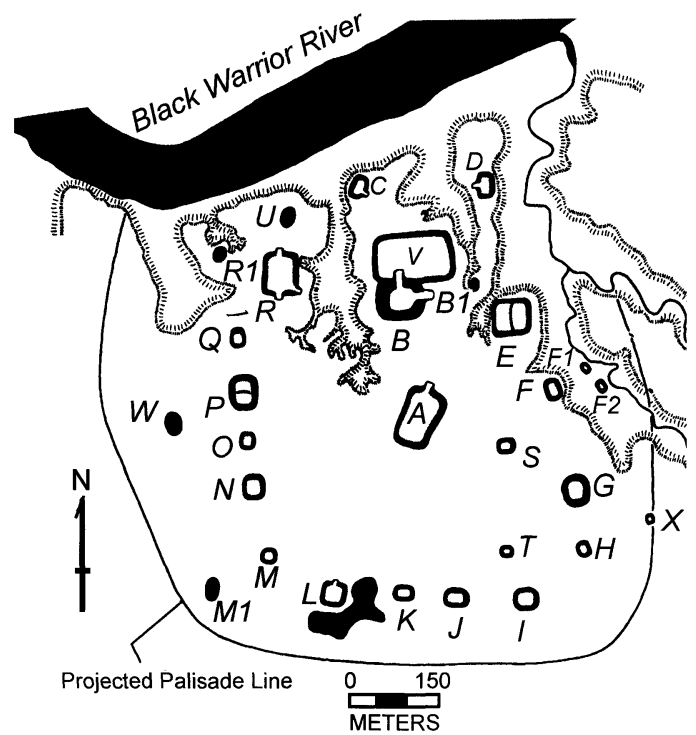

Figure 2. The Moundville site.

Early in the fourteenth century, there was an apparently rapid evacuation of the general population, leaving only a small elite group and their retainers as residents of Moundville (Steponaitis 1998). The balance of the population inhabited scattered small farmsteads. Three not necessarily mutually exclusive propositions have been suggested to account for population dispersal (Knight and Steponaitis 1998:19). Local resources may have been depleted by the large late Moundville I-early Moundville II site population, forcing movement of the bulk of the population elsewhere. Alternatively, removal of the non-elite may have been aimed at increasing the sanctity of the Moundville center. Finally, the consolidation of regional political power by the Moundville elite may have resulted in a relatively peaceful period, reducing the need to live within a palisaded settlement. Regardless of cause, the effect of this physical separation would have been to accentuate the symbolic distancing of elites from the rest of Moundville society. At the same time, burials at the site increased significantly in number, leading researchers to interpret a change in site function from town to necropolis (Knight and Steponaitis 1998:19). The most lavish burials appear to date to this interval (e.g., Peebles and Kus 1977).

By the end of the fourteenth century (late Moundville II), there is evidence that a number of the platform mounds had been abandoned, though 


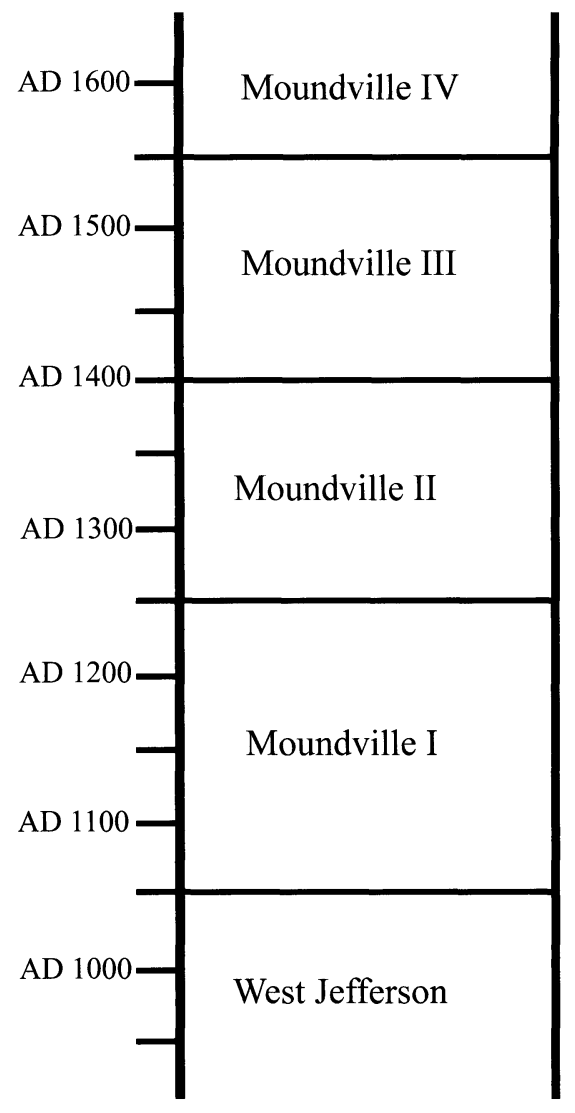

Figure 3. Moundville chronology.

others continued to be inhabited and underwent additional building episodes. Although the intensity of prestige-goods exchange appears to have diminished somewhat, elite burials continued to be lavish, and many of the iconographically rich SECC items are attributed to this interval (Knight and Steponaitis 1998:19). Additional secondary centers were established at this time, suggesting the destinations of at least some of the elites who had evacuated the site.

By approximately A.D. 1450 (Moundville III), additional mounds were abandoned, with only three on the northern side of the site still occupied (Knight and Steponaitis 1998:21). Only a small off-mound residential area was occupied. The numbers of burials declined, mounds ceased their mortuary function, and nucleated settlements reappeared in the valley. Cemeteries at outlying settlements were established at this time, suggesting that Moundville's role as necropolis had waned. The evidence is taken to represent the decline of
Moundville's political power. By the end of the sixteenth century, Moundville had been entirely abandoned.

Knight (1998) and previously Peebles (1983) have built the case that the spatial arrangement of the plaza periphery mound group provided a diagrammatic representation of the hierarchical and corporate-group relationships among the newly emerged Moundville elite. Surrounding the largest mound in the center of the plaza, the plaza periphery mounds are organized in what appear to be pairs of large and small mounds, with the largest of the major mounds located on the north edge of the plaza, and as the distance from this northern tier increases, the sizes of the major mounds decrease. Mound burials more frequently occur in the minor mounds, such that the pairs were originally interpreted as representing domicile (major mound) and temple or charnel house (minor mounds) functions (Knight 1998). Each pair is suggested to represent a different elite corporate group organized in order of descending status from north to south. Recent excavation indicates that this dichotomy is too simplistic, however; architecture on major mounds suggests more than one function and a domiciliary function for the minor mounds seems also to be the case (Knight 1995; 2001a).

\section{Previous Moundville Faunal Studies}

The archaeological research on which the foregoing framework is based has also produced information about dietary patterns of the Moundville elite, including the basic character of elite patterns of meat consumption. Lauren Michals (1992) reported on faunal samples from several socially differentiated contexts at Moundville, including off-mound middens north and west of Mound $\mathrm{R}$ that are interpreted as elite residential areas occupied during the late Moundville I phase. Michals found that anatomical unit representation is indicative of deer provisioning and she identified a positive correlation between social rank and increased representation of upper forequarters and axial remains.

Welch's (1991, 1998) excavations at the White site, a Moundville III single mound center located $13 \mathrm{~km}$ from Moundville, produced a modest faunal assemblage associated with the elite residents of that site. Welch's (1991) original analysis assumed that the site served as a local center in the 
Moundville chiefdom's political economy. The revised history of the latter cast doubt that the two sites were integrated in this way. Constructed at the time when Moundville mounds were being abandoned, the White site includes one of two cemeteries outside of Moundville and evidence for population nucleation there during the late Moundville III subphase, which may reflect the progressive disintegration of the Moundville chiefdom (Welch 1998:164-165). With respect to the fauna, overall taxonomic contributions to the total admittedly small sample are not significantly different from those documented for either Lubbub Creek or Michals's small sample from Moundville (Welch 1991). Deer body-part representation suggests off-site butchering and possibly provisioning by smaller communities. In contrast to the pattern reported by Michals, hind limbs are considerably better represented than forelimbs. Other than fox, ${ }^{1}$ no "exotic" carnivores are represented in the White site sample, and no birds other than turkey and a teal-sized duck were identified.

Pertinent to the role of meat and animal products in the broader foodways patterns of the Moundville chiefdom are several ethnobotany and trace element studies. Research focused on statusrelated variation in plant processing and consumption evidence in the ethnobotanical record (Welch and Scarry 1995) provided greater evidence for plant food (maize, nuts) processing at outlying settlements than at Moundville, but found no significant difference in evidence for the amount consumed. Similarly, stable isotope analysis of bone samples from Moundville burials by Schoeninger and Schurr (1998) failed to distinguish social differences in either amount of maize in the diet (measured by stable carbon isotope ratio) or in the contributions made by fish (stable nitrogen isotope). An earlier study (Peebles and Schoeninger 1981) of strontium levels indicated that elites consumed more meat (from terrestrial animals) than did commoners. These studies suggest that at least for the Moundville chiefdom, the kinds of differences that may be discovered in faunal samples from socially distinct contexts are largely symbolic of those social distinctions, rather than contributing in a profound way to differences in nutritional health.

At present, data on animal use by commoner households of the Moundville polity are not exten- sive. Samples of fauna recovered from three nearby farmsteads, Oliver (Michals 1997), Mill Creek site (Michals 1987), and 1TU768 (Holm 1997), located upriver from Moundville, are small and dominated by large mammal remains. Although the data are limited, it does appear that more primary butchering refuse is found at this class of sites (Michals 1997). One exceptional rural site is the Grady Bobo site (1TU66), where excavation of a large shallow Moundville I pit produced an exceptionally high percentage of bird remains (Holm 1997; Jackson 2002). It is unlikely that the pit represents everyday household refuse, however, and how rural ritual may have played a role in the early stages of the development of the Moundville polity is an issue currently under study (Maxham 2000; Scarry and Scarry 1997).

\section{The University of Alabama Mound Excavation Program}

The present interpretation of the history of mound construction and occupation at Moundville is in no small part the result of University of Alabama excavations between 1989 and 1998, directed by Vernon J. Knight. Knight's excavations in the flanks and summits of five mounds have provided data for a number of new and important studies (Knight 1992, 1995, 2001a; Markin 1997; Ryba 1995; Taft 1996; Wilson 2001), clarifying chronology and expanding our understanding of mound summit activities. Knight $(1989,1992)$ and his student Robyn Astin (1996) also reanalyzed materials from nine other mounds produced by previous investigations. The University of Alabama project produced faunal samples from the five mound contexts. Our analysis of these (Jackson and Scott 2002), in particular, large samples from Mounds Q and G, are the focus of this discussion.

Mounds $\mathrm{Q}$ and $\mathrm{G}$ were initiated late in the Moundville I phase and occupied during Moundville II and Early Moundville III (ca. A.D. 1250-1450). Mound Q, located in the northwest corner of the plaza, is a modest construction just under $4 \mathrm{~m}$ tall and approximately 45 by $30 \mathrm{~m}$ at its base. Mound summit and flank excavations produced a wide array of material. Much of the bone was recovered from the northern flank where a thick midden deposit was encountered. Summit excavation exposed architectural remains representing multiroom domestic structures. Excava- 
tions produced abundant pottery representing both cooking and serving vessels, subsistence remains, and a wide array of artifacts and debris representing craft goods manufacture. Craft activities included copper working, production of tabular stone artifacts, and woodworking (Knight 2001a; Markin 1997; Wilson 2001). There is also abundant evidence for pigment use, including minerals, paint palettes, and sherds from vessels used for mixing paints. In addition to the evidence that the structure served a residential function and a place for artifact crafting, other remains, including highly fragmented bits of human bone, tobacco, and yaupon (Ilex vomitoria, the leaves of which were used to make "black drink," an emetic concoction used in southeastern Indian purification rituals) point to more esoteric activities (Knight 2001a). Subsistence-related botanical remains, analyzed by Scarry (1996), are dominated by corn with modest amounts of nutshell, squash, chenopod, knotweed, and maygrass. Scarry's analysis indicates a greater amount of corn was processed in non-elite residence areas than is the case for elite contexts at the northern end of the site. The latter, dating to the late Moundville I phase when the site's residential population peaked and during the most vigorous construction period, is interpreted to represent the higher level of provisioning needed to support the site's residents at that time. After Moundville's population dispersed, local fields apparently could meet the needs of those still residing there (Knight 2001a).

Mound G, located on the southeast margin of the plaza, is a larger structure, $6.5 \mathrm{~m}$ high and roughly 60 by $60 \mathrm{~m}$ square (Knight 1995). Flank trenches revealed four building stages dating from early Moundville II through early Moundville III, coeval with the excavated deposits of Mound Q. Summit excavations were not conducted but 25 test holes placed there by Clarence Moore in 1905 failed to produce burials, indirectly indicating its residential function (Knight 2001a). Midden deposits on the mound's flank produced artifacts and botanical and faunal remains. A diverse assemblage is represented by the ceramic sample. Compared with that from Mound Q, the assemblage from $\mathrm{G}$ is distinguished by a higher representation of bottle forms, reflecting the more privileged lifestyle of Mound G's residents (Knight 2001a). There were also fewer hemispherical bowls, which on Mound Q were used for mixing paint. A striking difference in material culture is the paucity of evidence for craft manufacture. Ethnobotanical data, like that from Mound Q, suggest high consumption of corn and similar levels of processing.

According to Knight (2001a), both mounds represent platforms on which Moundville elites resided, but the evidence suggests that we should not assume equivalent status within the broad superordinate social category. Just as the mounds themselves suggest social distinctions in their relative sizes and position around the plaza, differences in the activities of the elites residing on Mounds $G$ and Q appear to correspond to different positions in social space. Knight suggests that the residents of Mound $\mathrm{G}$ were more elite than their counterparts on Mound Q, which provided greater access to certain categories of artifacts and allowed them to remain aloof from the day-to-day activities of Moundville's population. In contrast, those residing on the more modest Mound Q actively interacted with elites and non-elites through their artisanry, ritual practices, and ritual bone manipulation. The social distinction drawn on the basis of artifacts and inferred activity differences can be further evaluated through a comparison of the faunal samples from the two mounds.

\section{Analysis}

Mound Q produced 10,577 specimens from control trenches recovered by a 6-mm-mesh screen (number of identified specimens or NISP $=9,628$ ). Flotation samples added 2,587 specimens to the sample. Controlled excavation of Mound G produced 3,299 specimens (NISP $=3,119$ ) by screening and 60 additional identifiable specimens in analyzed flotation samples. In addition, bone from unscreened reference trench excavation was scanned to identify taxa not represented in the controlled samples and to collect additional information on deer element representation and breakage patterns. These were kept separate analytically. At least 58 taxa are represented, 45 species in the Mound Q sample and 34 from Mound G (Table 1). Examination of reference trench material yielded one additional taxon, a whooping crane (Grus $c f$. americana) from Mound Q. The other much smaller samples from other mound excavations produced only one additional species, woodchuck (Marmota monax) (Jackson and Scott 2002). 
Table 1. Taxa Identified in Mounds Q and G 6-mm Samples.

\begin{tabular}{|c|c|c|c|}
\hline Taxon & Common Name & $\mathrm{Q}$ & $\mathrm{G}$ \\
\hline Didelphis virginiana & Opposum & $\mathrm{X}$ & $\mathrm{X}$ \\
\hline Sylvilagus floridana & Eastern Cottontail & $\mathrm{X}$ & $\mathrm{X}$ \\
\hline Sylvilagus aquaticus & Swamp Rabbit & $X$ & $\mathrm{X}$ \\
\hline Peromyscus sp. & Mouse & $\mathrm{X}$ & \\
\hline Cricetidae & Rat/Mouse & $\mathrm{X}$ & $\mathrm{X}$ \\
\hline Sciurus carolinensis & Eastern Gray Squirrel & $X$ & $\mathrm{X}$ \\
\hline Sciurus niger & Eastern Fox Squirrel & $\mathrm{X}$ & $\mathrm{X}$ \\
\hline Castor canadensis & Beaver & $X$ & $\mathrm{X}$ \\
\hline Procyon lotor & Raccoon & $\mathrm{X}$ & \\
\hline Mustela vison & Mink & $X$ & \\
\hline Mephitis mephitis & Skunk & $\mathrm{X}$ & $\mathrm{X}$ \\
\hline Lynx rufus & Bobcat & $X$ & \\
\hline Felis concolor & Cougar & $\mathrm{X}$ & \\
\hline Ursus americanus & Black Bear & $\mathrm{X}$ & $\mathrm{X}$ \\
\hline Urocyon cinereoargenteus & Gray Fox & & $\mathrm{X}$ \\
\hline Canis familiaris & Domestic Dog & $\mathrm{X}$ & $\mathrm{X}$ \\
\hline Canidae & Dog & $\mathrm{X}$ & $\mathrm{X}$ \\
\hline Carnivora & Carnivore & $\mathrm{X}$ & $\mathrm{X}$ \\
\hline Odocoileus virginianus & Whitetail Deer & $\mathrm{X}$ & $\mathrm{X}$ \\
\hline Bos/Bison sp. & Cow/Bison (cf. Bison) & & $\mathrm{X}$ \\
\hline Eudocimis alba & White Ibis & $\mathrm{X}$ & \\
\hline Branta canadensis & Canada Goose & $\mathrm{X}$ & $\mathrm{X}$ \\
\hline Aix sponsa & Wood duck & $\mathrm{X}$ & \\
\hline Aythya americana & Redhead & $\mathrm{X}$ & \\
\hline Aythya marilla & Greater Scaup & $\mathrm{X}$ & \\
\hline Anatidae & Medi & $\mathrm{X}$ & $\mathrm{X}$ \\
\hline Grus canadensis & Sandhill Crane & & $\mathrm{X}$ \\
\hline Buteo jamaicensis & Redtail Hawk & $\mathrm{X}$ & $\mathrm{X}$ \\
\hline Buteo sp. & Hawk & $\mathrm{X}$ & \\
\hline Falco peregrinus & Perigrine Falcon & & $\mathrm{X}$ \\
\hline Meleagris gallopavo & Turkey & $\mathrm{X}$ & $\mathrm{X}$ \\
\hline Colinus virginianus & Common Bobwhite & & $\mathrm{X}$ \\
\hline Corvus brachyrhynchos & Crow & $\mathrm{X}$ & \\
\hline Ectopistes migratorius & Passenger Pigeon & $\mathrm{X}$ & $\mathrm{X}$ \\
\hline Passerine & Son & & $\mathrm{X}$ \\
\hline Chelydra serpentina & ping Turtle & $\mathrm{X}$ & \\
\hline $\begin{array}{l}\text { Chrysemys pictal } \\
\text { Pseudemys floridana }\end{array}$ & Painted/Cooter & $\mathrm{X}$ & \\
\hline $\begin{array}{l}\text { Chrysemys/Graptemys/ } \\
\text { Pseudemys sp. }\end{array}$ & Painted/Map/Cooter & $\mathrm{X}$ & \\
\hline Terrapene carolina & Box Turtle & $\mathrm{X}$ & $\mathrm{X}$ \\
\hline Sternotherus sp. & Musk Turtle & $\mathrm{X}$ & \\
\hline Kinosternidae & Mud/Musk Turtle & $\mathrm{X}$ & $\mathrm{X}$ \\
\hline Apalone sp. & Turtle & $\mathrm{X}$ & $\mathrm{X}$ \\
\hline Coluber/Masticophus sp. & Racer/Coachwhip & $\mathrm{X}$ & \\
\hline Viperidae & Viper & $\mathrm{X}$ & \\
\hline Rana/Bufo sp. & Frog/Toad & $\mathrm{X}$ & \\
\hline Amia calva & Bow & $\mathrm{X}$ & \\
\hline Atractosteus spatula & Alligator Gar & $\mathrm{X}$ & \\
\hline Lepisosteus platystomиs & Short Nosed Gar & $\mathrm{X}$ & \\
\hline Lepisosteidae & Gar & $X$ & $\mathrm{X}$ \\
\hline Ictiobus bubalus & Small Mouth Buffalo & $\mathrm{X}$ & $\mathrm{X}$ \\
\hline Moxostoma carinatum & River Redhorse & $\mathrm{X}$ & $\mathrm{X}$ \\
\hline Moxostoma poecilurum & Blacktail Redhorse & $\mathrm{X}$ & \\
\hline Moxostoma sp. & Redhorse sp. & $\mathrm{X}$ & $\mathrm{X}$ \\
\hline Pylodictus olivaris & Flathead Catfish & $X$ & \\
\hline Ictalurus furcatus & Blue Catfish & $\mathrm{X}$ & \\
\hline Ictalurus punctatus & Channel Catfish & $\mathrm{X}$ & $\mathrm{X}$ \\
\hline I. furcatus/punctatus & Blue/Channel Catfish & $\mathrm{X}$ & $\mathrm{X}$ \\
\hline Ictulurus melas & Black Bullhead & $\mathrm{X}$ & \\
\hline Micropterus salmoides & Largemouth Bass & $\mathrm{X}$ & \\
\hline Micropterus sp. & Bass & $\mathrm{X}$ & $\mathrm{X}$ \\
\hline Micropterus/Pomoxis & Bass/Crappie & $\mathrm{X}$ & \\
\hline Aplodinotus grunniens & Freshwater Drum & $\mathrm{X}$ & $\mathrm{X}$ \\
\hline Carcharhinidae & Shark & & \\
\hline
\end{tabular}

Deer and large mammal (comprised almost entirely of fragments of deer bone too small to identify confidently) make up the bulk of the samples. Small mammals, birds, reptiles, and fish make near-identical contributions based on relative bone weight. Following deer, turkey provides the nextgreatest contribution to both samples. Several of the taxa, including mice, rats, and frog/toad, are assumed to be commensal. Presumably, the remaining taxa, including at least 17 mammals, 15 birds, 7 reptiles, and 12 fish, were consumed or used in some other way (Jackson and Scott 2002).

\section{Deer and Large Mammal}

By count, deer and large mammal comprise 70 percent of the identifiable portion of the sample; by weight their contribution exceeds 90 percent (Figure 4). Deer comprise 13-15 percent of the site Minimum Number of Individuals (MNI). Deer element representation corresponds well with patterns identified in elite contexts by Michals (1992) for Moundville and from elite contexts at other Mississippian sites. Element representation was first evaluated in the following manner. Ignoring symmetry (left or right elements), the number of element portions (e.g., proximal humerus, distal humerus) was tallied and expressed as a percentage of the minimal animal units (MAU, essentially the number of carcass portions necessary to account for the most common element portion) (Jackson and Scott 2002). In Figure 5, element portions are grouped into broad utility categories, following Kelly (2001). Anatomical units represented in the north flank midden of Mound Q are primarily highutility cuts, specifically upper fore- and hindquarters. As Michals noted in her analysis of elite samples from elsewhere at Moundville, forequarters are somewhat better represented than hind limbs. Elements representing low and medium utility cuts or primary butchering debris are decidedly more poorly represented, but are present. MAU derived from Mound $\mathrm{G}$ deer elements presents a similar pattern, although hindquarters are better represented. Posterior axial material—-lumbar vertebrae and sacra-is also better represented in the Mound G sample, suggesting that either a wider range of cuts was consumed there or else there was less destruction of this portion of the skeleton (the lumbar region contains the tenderloin, the source of filet mignon). 


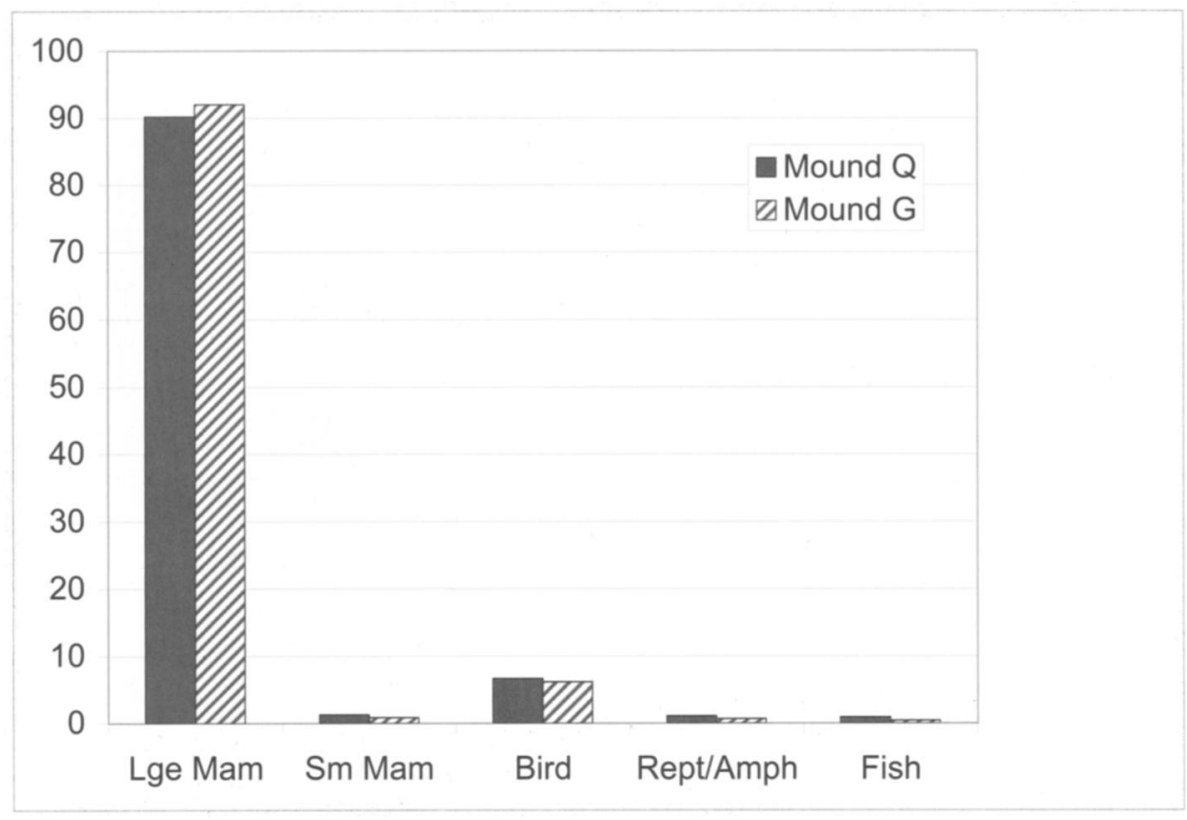

Figure 4. Proportional contributions of major taxonomic groups based on weight.

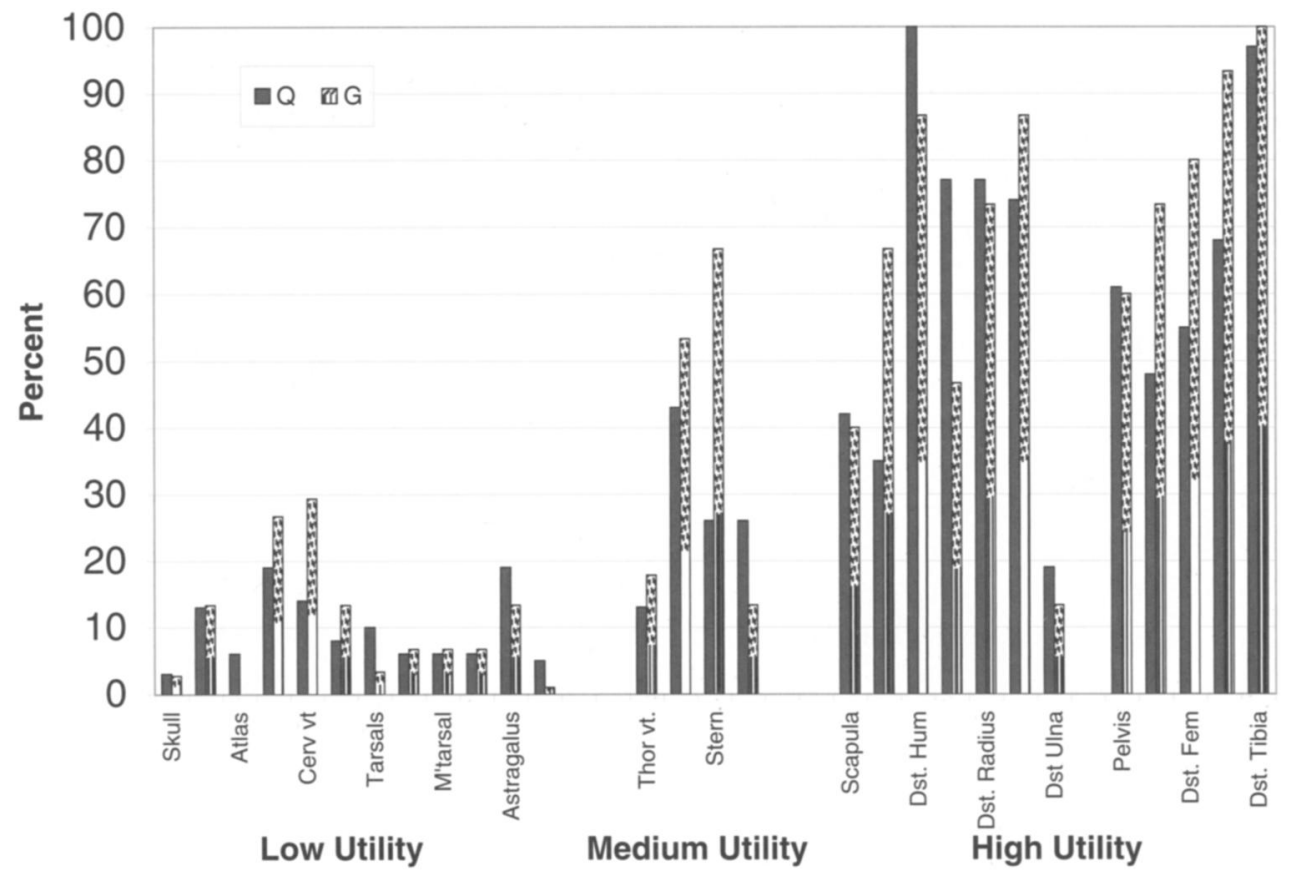

Figure 5. Relative proportions of low, medium and high utility carcass parts reflected by the percent of expected minimum anatomical units. 


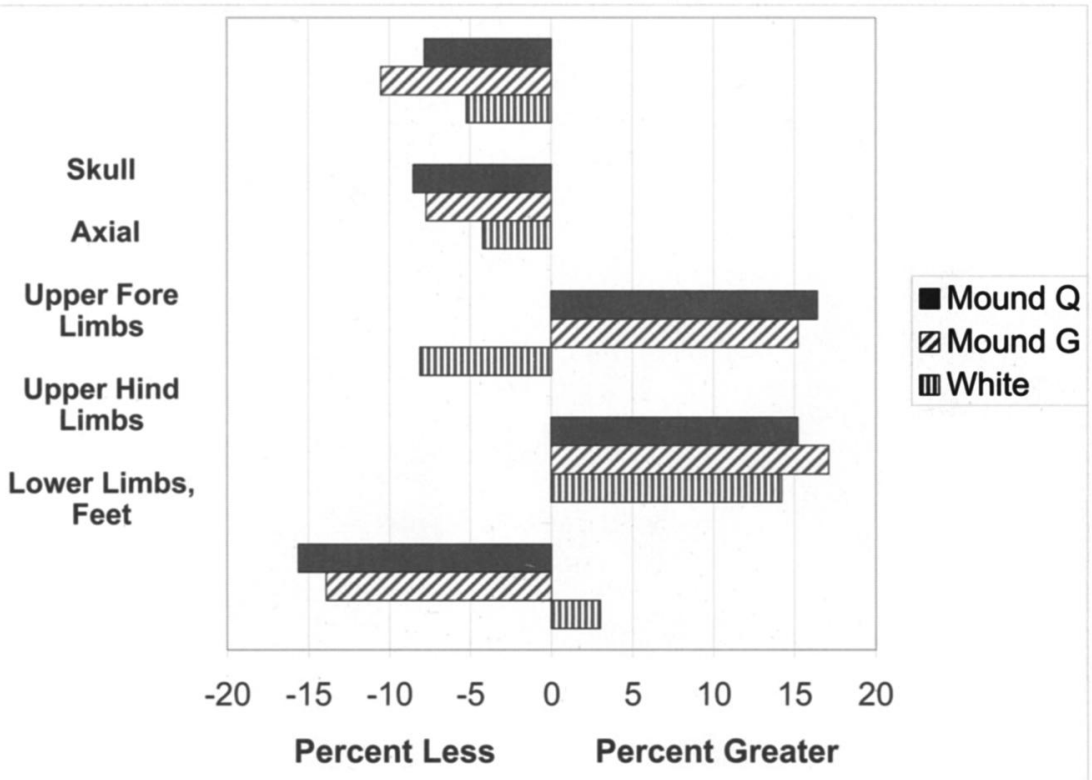

Figure 6. Proportions of major anatomical units, measured by weight, represented by Mound Q, Mound G, and White site deer remains, in reference to proportions of units in a complete skeleton.

In addition to the graphical assessment of the MAU pattern, we compared the percent MAU distribution for each sample to those of an index of carcass portion utility; for comparability with previous work we used Binford's (1978) modified general utility index (MGUI) calculated for caribou. ${ }^{2}$ We also assessed the potential effects of cultural or natural attrition on the samples by comparing percent MAU with element portion bulk bone-density values provided by Lyman $(1984,1991)$. In both cases, rank order correlation was used to assess these relationships, using Spearman's rank order correlation statistic $\left(r_{s}\right)$. Significant positive rank order correlations exist between percent MAU and MGUI (for Mound Q, $r_{s}=.521$; for Mound G, $r_{s}=$ .66). In contrast, no significant correlation was found between percent MAU and bulk-density values, suggesting that the sample, from a preservation standpoint, is reliable.

Despite the lack of correlation between MAU and bulk density, there is still a possibility that attrition is responsible for the dominance of upper limbs. An additional control is provided by combining the weights of deer elements with that portion of the assemblage classified as large mammal. This is possible because in the analysis large mammal specimens were classified according to gen- eral anatomical region (skull, axial, longbone, and indeterminate, the latter comprised mainly of cancellous bone fragments). If extensive fragmentation is responsible for reduced identifiability, bone will be relegated to the large mammal category. Figure 6 compares proportional contributions by weight of bone identified as deer and large mammal bone and assigned to anatomical categories, expressed in terms of the expectable proportional contributions of these anatomical units to the total skeleton weight of a modern deer. The similarity reinforces the interpretation that attrition is not significantly responsible for the element patterning exhibited by deer. Although not reported here, patterning of deer elements recovered from reference trenches is identical (Jackson and Scott 2002).

Overall, element representation is similar to that observed in previous studies of deer remains from elite Mississippian contexts, with generally low proportions of primary butchering debris and high proportions of meat-bearing elements. In a previous study (Jackson and Scott 1995a; Scott 1983), deer element distribution exhibited by remains recovered from Lubbub Creek was contrasted with that of a rural single-family farmstead, the Yarborough site also located in the Tombigbee drainage. We interpreted the complementary distributions of 


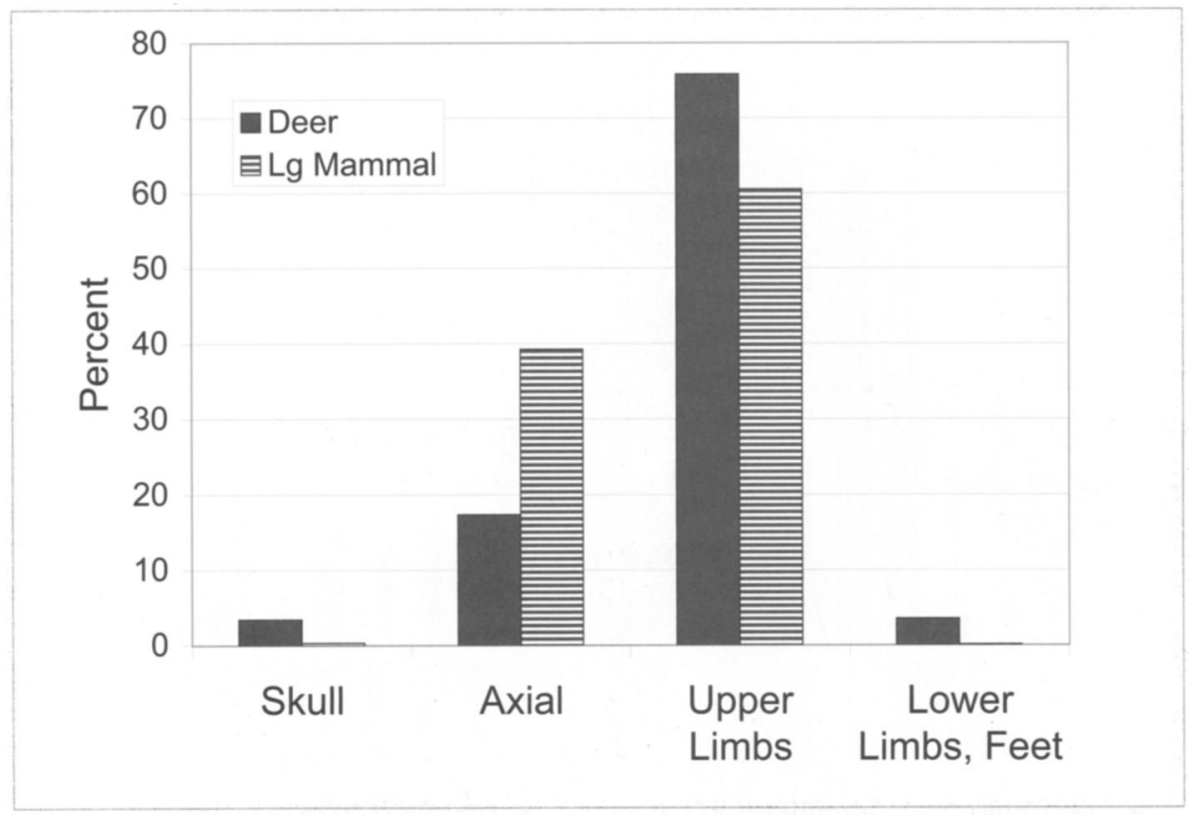

Figure 7. Comparison of deer and large mammal anatomical unit representation.

deer elements in the two assemblages to reflect at least periodic provisioning of the Lubbub Creek elite by hunters residing at outlying sites. Nearer to Moundville in the Black Warrior drainage, Welch (1991) also suggested that the deer remains from the single mound White site reflected provisioning. The similarity in patterning among the mound samples and that from the White site can be observed by comparison of bone weight contributions to general anatomical categories, expressed with reference to these categories in the proportions found in a complete deer skeleton (Figure 7). While we don't disagree with Welch's characterization of the White site data, it is interesting to note that there is greater evidence for primary butchering (metapodials, feet) there than is present in the Moundville sample, suggesting local hunting. Moreover, as Welch noted, forequarters are under-represented compared to hindquarters, in contrast to the more even representation in the Mound G and Q samples. Nonetheless, we are reasonably confident that the similarities in element representation in the deer remains from these elite contexts reflect similar economic relationships.

Accounting for the variable distribution of forelimbs vs. hind limbs in Moundville elite contexts may present some difficulties. In the north of Mound R elite contexts analyzed by Michals (1992), as well as elite contexts in the Mississippian settlement at Lubbub Creek (Scott 1983), forelimbs are more plentiful. Hind limbs and forelimbs are roughly equally represented in the Mounds Q and G samples. The high representation of forelimbs in these cases runs counter to assessments of differential carcass part utility (e.g., Binford 1978, 1984; Binford and Bertram 1977; Metcalfe and Jones 1988). Only at the White site are hind limbs better represented. Also interesting and possibly related is the fact that hind limbs present in the Mound Q and G samples tend to be from somewhat younger individuals than those represented by forequarters (Jackson and Scott 2002). This observation is based on patterns of epiphyseal fusion, an admittedly very coarse estimate of an individual's age (Purdue 1983). It is possible that the pattern represents a cultural preference that defies more "rationally" determined predictions about utility. However, two other (not necessarily mutually exclusive) explanations can be proposed. One possibility is that transport considerations warranted smaller, more manageable cuts. Shoulders can be easily removed from the carcass by cutting through the soft tissue behind the scapula, rendering a small meat package of about 5-6 kg. Hindquarters are considerably more difficult to disarticulate and are larger and more irregularly shaped. This could explain why those 


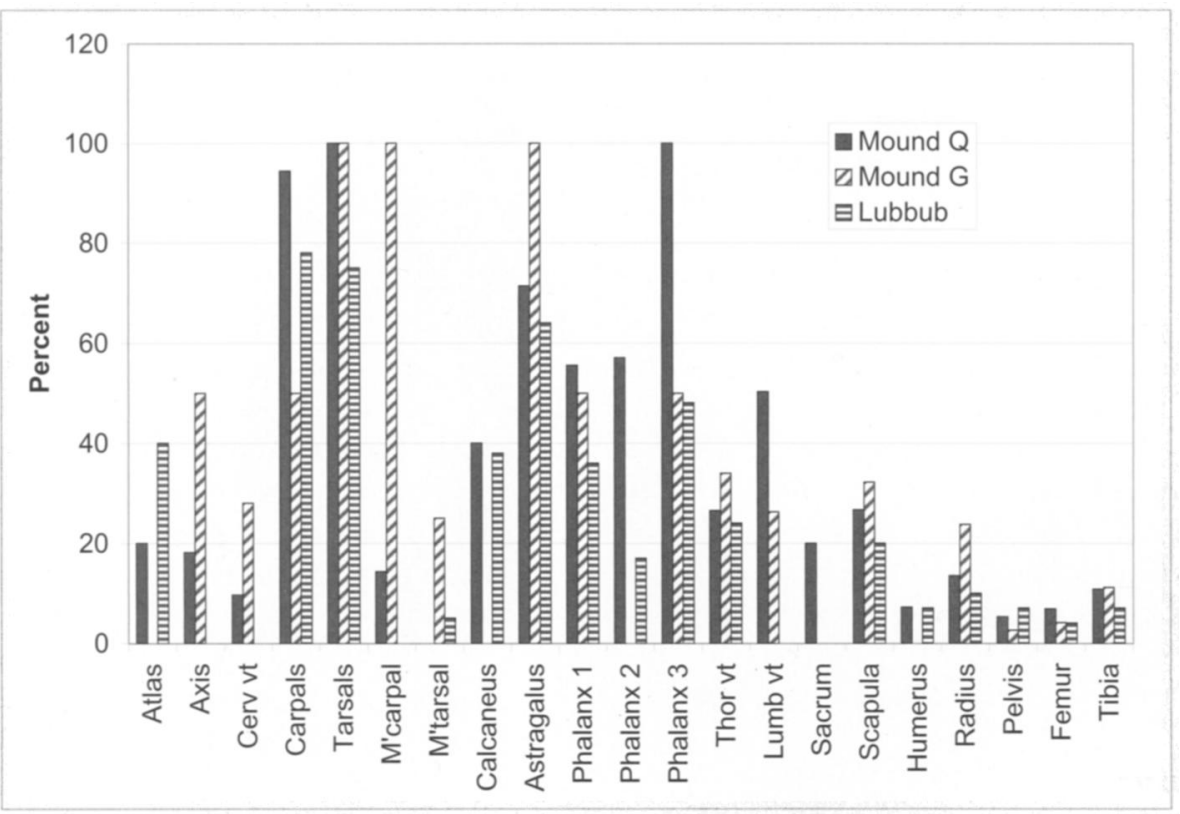

Figure 8. Comparison of the degree of deer element fragmentation, expressed as the proportion of element specimens 50 percent or more complete. Data from Mound Q, Mound G, and Mississippian period Lubbub Creek Archaeological Locality assemblages.

hindquarters that were carried to Moundville were more often from younger and presumably, on average, smaller individuals. A second explanation focuses on tension that may have existed between hunters and the provisioned elite. By supplying forequarters to the elite, hunters may have abided by the letter of the law in providing the requisite contribution of venison, while maximizing the amount of remaining meat available for their own families. In the case that either or both of these scenarios are correct and at the same time food utility indices do indeed reflect prehistoric meat valuation, it is interesting to note the greater representation of hind limbs in the Mound G sample.

One way to assess the intensity of deer utilization is by examining patterns of bone breakage. Initial butchering, chopping to produce pieces appropriately sized for cooking vessels, further processing for marrow and grease, and finally natural postdepositional factors all contribute to the extent to which bones are found in fragmentary condition (Scott 1983:286-298). To examine fragmentation of identifiable deer bones, each specimen was recorded as a fraction of a whole element. While comparable data are not presently available from commoner contexts directly related to Moundville, they are available from Lubbub Creek, which thus provides something of a baseline for assessing fragmentation (commoner and elite contexts combined). Figure 8 compares the percentage of elements represented by specimens greater than 50 percent complete in the Moundville deer samples to those recorded for the Lubbub Creek sample (Scott 1983:Table 6). Overall, the Moundville samples have been subjected to less fragmentation, and those from Mound G even less than Mound Q. Of particular note is the greater percentage of more complete vertebrae in the Moundville samples (axis, cervical, and lumbar vertebrae). This suggests that the vertebral column was not subjected to the degree of processing evident in the Lubbub sample. If boiled in stews, vertebrae were simply discarded once the meat fell away, rather than being further processed to render grease. Similarly, phalanges are less fragmented, suggesting that these were more often discarded whole, without being split open for marrow. In contrast, long bones exhibit similar fragmentation at both sites, with only small percentages (less than 15 percent) greater than 50 percent complete, indicating that these bones were regularly broken to extract marrow. Even greater processing is in evidence at well- 
documented Mississippian farmsteads such as the Yarborough site in northeast Mississippi (Jackson and Scott 1995a; Scott 1982).

\section{Bison}

Three elements, a metatarsal, a lateral malleolus, and a first phalanx, all from Mound $G$, were identified as probable bison. The three were recovered near one another and appear to have been the result of a single disposal episode. All of the elements are from a calf too young to be absolutely certain of our provisional identification. However, clear aboriginal (stone tool) skinning marks present on the anterior face of the first phalanx running perpendicular to the shaft lend credence to the identification; cattle were not introduced to the area until the late nineteenth century by which time iron tools were in common use. Four additional specimens, a rib fragment and an indeterminate fragment from Mound G, and two indeterminate fragments from Mound Q, identified as very large mammal, may also represent bison. The only other possible candidates for this identification are bear, which frequently can be recognized on the basis of surface texture, and elk, which are absent from late Holocene archaeological assemblages as far south as central Alabama. Based on size and morphology, bovid is the most likely candidate.

Our present evidence for bison east of the Mississippi River in the mid-South dates to the protohistoric period. Among the sites producing bison are the protohistoric/historic Futorian site (Johnson et al. 1994) and at ImmoKakina' $\mathrm{Fa}$ ', an early historic Chickasaw site (Scott and Tuma 1998), both in northeast Mississippi, and the Milner site, a midseventeenth-century site on the Coosa River in Alabama (Smith et al. 1993). Since bison seem to have been a very late intrusion east of the Mississippi, we suspect that the Mound G specimens most likely represent exchange of bison products. We suggest these bones arrived as riders on bison hides used to transport dried meat or other Plains products, left in the hide to serve as handles for the bundles, a pattern documented at Plains village sites (e.g., Jackson and Scott 1992). As for the source of bison products, we note that Schambach (1993) has presented a convincing argument that Spiro served as a conduit that funneled Plains products into the Mississippian world. Given other evidence of connections between Spiro and Moundville, the presence of bison at the latter lends support to Schambach's case.

\section{Other Mammals}

Excluding probable commensal taxa (mice and rats), 14 mammalian species were identified in the Mound samples (Table 1), though none in great numbers. Gray squirrels are most plentiful, followed by fox squirrels, along with smaller numbers of small and medium-sized mammals that commonly occur in southeastern faunal assemblages, such as cottontail, swamp rabbit, opossum, raccoon, and dog.

That gray squirrel remains outnumber those of fox squirrels is interesting in light of Moundville's developmental history. Fox squirrels are more likely to be found in open habitats, while gray squirrels inhabit woodland settings. Scott (1983) found significant increases in the ratio of fox squirrel to gray squirrel from Late Woodland to Mississippian phases at Lubbub Creek, corresponding to an increased representation of domesticated crops in the archaeobotanical record. The shift in taxa was interpreted as the result of land clearance for food production. In the Moundville case, just the opposite pattern is exhibited. The ratio of fox squirrel to gray squirrel (based on NISP) decreases from .85 (35:41) in Moundville II subsamples to .09 (5:51) in Moundville III subsamples. The shift suggests that after the dispersal of the general populace early in Moundville II phase, local forests returned to abandoned fields, so that by Moundville III, gray squirrel was the dominant species. Although overall cottontails, also more common in open habitats, outnumber swamp rabbits in the Mound Q sample, the latter are found only in Moundville III subsamples, providing some corroboration for the trend. Only swamp rabbit, the larger of the two species, was identified in the Mound G sample.

Three taxa (bobcat, cougar, and bear) fall into the category of "dangerous prey" and are interesting in light of their possible roles in the symbolization of power. Bear occurs in both mound samples while cougar and bobcat are present only in Q. All three species are represented by either limb or vertebral elements; none is burned or otherwise modified. Fox might also fall into this category, not because it is a particularly dangerous animal, but because of its potential supernatural connotations. It is present only in the Mound G sample. Alterna- 
tively, fox may reasonably be included with other fur-bearing taxa, such as raccoon, mink, and skunk, which are present in both samples, but are slightly more common from Mound Q, perhaps reflecting the craft activities there.

One interesting characteristic of both of the Moundville samples is the paucity of commensal rodents in the mound samples examined. We have found in other elite samples an abundance of rats and mice, which we have surmised were attracted to elite residential areas because of their proximity to large storage structures containing the plant foods received as tribute. Only seven rodent bones, representing both mice and rats, were identified in 6-mm samples and an additional 26 in the flotation samples from Mound Q. Three additional rodent elements were identified in the Mound G 6-mm sample and none in the fine screen. By way of contrast, 227 rodent bones, nearly seven times as many, were identified from an elite house structure and associated midden at Crenshaw in southwest Arkansas (Scott and Jackson 1998), in a sample only 50 percent larger than the combined samples from mounds $\mathrm{Q}$ and $\mathrm{G}$. The paucity of rodent remains suggests that storage facilities were located away from the mounds (although it is possible that surplus grain storage at Moundville was not important).

\section{Birds}

Birds, dominated by turkey, comprise the second most plentiful taxonomic category. Turkey comprises 85-87 percent of the bird NISP identified to levels more specific than class. Turkey plus unidentifiable large bird constitutes 91-95 percent of bird remains measured by NISP and nearly 95-97 percent measured by weight. Waterfowl include Canada goose, wood duck, redhead, greater scaup, white ibis, sandhill crane, and whooping crane (from a reference trench sample), each with an MNI of 1. The white ibis is an uncommon inclusion in southeastern faunal assemblages, particularly from inland sites. Passenger pigeon is the second most common taxon $(\mathrm{NISP}=13, \mathrm{MNI}=$ 3). Six bones from raptors were identified in the Mound Q sample, but only one could be identified to species, a redtail hawk. Particularly significant is the presence of peregrine falcon in Mound G. The peregrine falcon is perhaps most telling of the status of the elite residents of the mound, being a cen- tral feature of Mississippian iconography, most often depicted in human bird form as a falcon warrior. As noted earlier, peregrine falcon remains are exceedingly rare in Mississippian faunal assemblages.

Turkey was likely second only to deer in the amount of meat a single taxon contributed to elite meals. Body, wing, and leg elements are well represented, although extremities (phalanges, pollex, tarsometatarsus) and skull elements are present as well, indicating that whole turkeys were prepared on the mounds. Sex composition was estimated based on the size of each element for both controlled samples and for turkey specimens from the reference trenches. Smith (1975), based on Schorger's (1966) study of the wild turkey, suggests that we should expect aboriginal kill assemblages to have more females and pre-adults than males, mirroring flock composition and reflecting the difficulty of capturing gobblers. Smith (1975:Table 18) found that males comprised an average of only 23 percent of turkeys from seven Middle Mississippi sites, based on the presence or absence of spurs on tarsometatari. In the Moundville samples males comprise 37 percent of the controlled sample by NISP, and 40 percent of the larger sample including bones from scanned proveniences, significantly different from Smith's results $\left(\chi^{2}=6.063\right.$, $p=.014)$. Why males are better represented in the Moundville sample is of some interest. Large gobblers simply may have been preferred by the elite. Manipulation of local turkey populations (raising wild poults?) raises another, though unevaluated, possibility.

\section{Reptiles and Amphibians}

A variety of turtles, including snapping turtle, aquatic emydids, box turtle, musk turtle, and softshell turtle, are represented by carapace and plastron fragments. Box turtle is the most common, based on both NISP and weight, followed by softshell turtle. Only two snake taxa were identified, including coachwhip or racer, represented by two vertebrae, and a viper represented by four vertebrae. Reptiles are less well represented in the Mound $\mathrm{G}$ sample, although sample size may be the cause.

\section{Fish}

Fish appear to have made a minor contribution to 


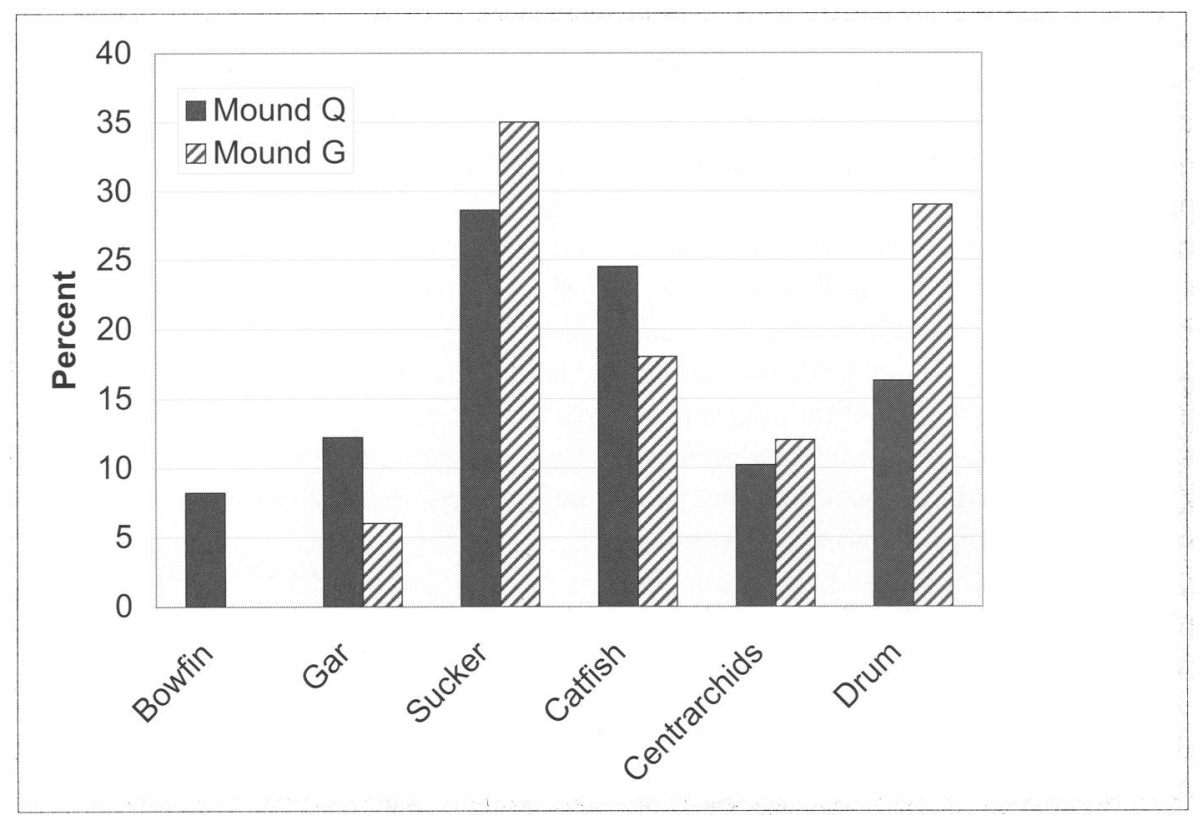

Figure 9. Relative contributions made by fish taxa to Mound $Q$ and Mound $G$ assemblages.

elite meals, compared to large mammal or large bird. However, the samples are diverse and there are some differences between the two. From Mound Q (6-mm fish NISP $=409)$, the single most abundant species is freshwater drum, comprising 16 percent of fish MNI (Figure 9). The most abundant family, suckers, including blacktail redhorse, river redhorse, and smallmouth buffalo, comprise nearly 29 percent of the sample. Catfish (25 percent of the fish sample) include mainly blue and channel cats, and a single black bullhead. Gars, which comprise 12 percent of the sample, include both alligator gar and shortnose gar. Modal body length for most taxa falls within the 30-45-cm range (standard length), although certain taxa, including gar, redhorse, and channel/blue catfish all had individuals in excess of $55 \mathrm{~cm}$, and one alligator gar specimen was from an individual greater than $100 \mathrm{~cm}$ in length. A general emphasis on river channel fishing is indicated by fish species composition, casting doubt on an oft-voiced suggestion of the importance of fishing in borrow-pit ponds scattered across the site (e.g., Walthall 1980:216), at least for provisioning the elite.

Fish composition in the Mound $\mathrm{G}$ sample lacks bowfin (Figure 9), although sampling error may be responsible given the small number of specimens (6.4-mm fish NISP $=88)$. Drum again makes the greatest contribution of any single taxon (29 percent), while suckers collectively constitute the largest portion of the sample (35 percent). Unlike the Mound Q sample, that from Mound G lacks individuals larger than $60 \mathrm{~cm}$. One unusual specimen in the Mound G fish sample is an unfossilized shark tooth. It is unmodified, and while it clearly indicates contact with coastal populations or a visit to the shore, it cannot be determined whether meat or simply the tooth was obtained.

\section{Discussion}

There is no reason to doubt that the residents of both mound summits were elite members of Moundville society, based on multiple lines of archaeological evidence. This social position afforded access to considerable variety in the meat portion of the diet, including choice cuts of venison, turkeys, and a variety of other, often uncommonly recovered taxa. Animals with hypothesized symbolic meaning are in evidence as well: bobcat, cougar, fox, black bear, white ibis, redtail hawk, sandhill and whooping cranes, peregrine falcon, and some unknown number of songbirds. Bison and shark reflect the farflung ties that the elite maintained in the Mississippian world. While there is evidence for provisioning or at least off-mound butchering, there is also evidence that culinary preparation occurred 
within each household although care to completely use animal products was apparently not important, judging from the relatively low level of bone fragmentation compared to other Mississippian sites in the region.

In the context of recent interest among archaeologists and ethnographers alike in the role of feasting in social and political interactions, our initial expectation was that the mound faunal assemblages would fit hypothesized profiles of feasting refuse. However, the deer element profiles and general diversity of the assemblage are not consistent with the expectation that bulk meat was the ultimate goal. In contrast, Kelly's (2001:347) interpretation of the sub-Mound 51 pit at Cahokia as a deposit produced by feasting is based on evidence for initial processing of deer elsewhere (a nearly complete absence of skull or feet) and considerable butchery waste (articulated and presumably uncooked vertebral columns, little bone breakage attributable to marrow extraction, etc.). Moreover, entomological evidence (abundant blowfly pupae) from this extraordinary pit feature indicates the disposal of raw meat presumably still attached to limbs (Kelly 2001:348). Other large taxa, including large river channel fish and a preponderance of swans, also suggest that the goal was to gather a large quantity of meat to supply the feasts, a faunal profile that was consistent throughout the strata of the pit. This simply is not the case for the Moundville samples.

While similarities between the Mound Q and Mound $\mathrm{G}$ assemblages are greater than the differences, it is those subtle differences that express distinctions among the elite social group, which Knight (2001) has established based on more durable classes of archaeological remains. Most striking is that the most unusual taxa-bison, shark, and peregrine falcon - are all from Mound G. Furbearing taxa, possibly related to craft production, are more common in Mound Q. Further, the sample from Mound $G$ is even less fragmentary than that from $\mathrm{Q}$, suggesting less-frequent bone processing or less-frequent consumption of stews. Differences in networks, as well as the activities through which those networks were maintained, seem to distinguish the faunal records of the two elite residential groups that inhabited their respective mounds.

In general, the variety of meat in the diet in the Moundville elite runs counter to the general Mis- sissippian pattern of faunal exploitation, which shows a decrease in the range of taxa utilized compared to Late Woodland assemblages (Muller 1997; Smith 1975). The narrower range is attributable to scheduling conflicts presented by intensive agriculture as well as a restructuring of the distribution of animal populations resulting from extensive field clearing and higher, more sedentary, human populations (Muller 1997:227; Scott 1983:322). Nonetheless, at least in the Moundville case, the luxury of variety appears to have been enjoyed, or perhaps required, by its elite residents.

\section{Conclusions}

The present study suggests that in addition to distinguishing broad contextual (feasting vs. private consumption) and social (elite vs. commoner) dimensions of prehistoric middle-range societies, faunal remains may be added to the list of artifact categories with which useful, sometimes subtle, distinctions in social rank can be identified. In the Moundville case, differences in rank between mound-top households based on ceramic assemblages, craft debris, and other artifacts are mirrored in differences in foodways and other uses of animal products. The differences reflect broad principles related to economic organization, differential access, and animal symbolism. As stated at the outset, we don't intend to propose a formulaic method for ascertaining rank differences in Mississippian societies. However, to the extent that foodways incorporate cultural meanings related to political power, social differences, ethnic identity, or ritual matters, faunal assemblages resulting from particular activities or from different household contexts can be expected to vary as a consequence. For the Mississippian case, some of these can be predicted by "objective" measures such as utility or wastefulness, while other measures are clearly rooted in the symbolic imagery of prehistoric southeastern Indian culture. In relying on the latter class of measures, our work with Mississippian societies is clearly informed by the ethnographic record of myth and beliefs of southeastern peoples. However, the cross-cultural value placed on meat and meat eating (e.g., Kent 1989) leads us to suggest that symbolic attributes of animals may have broader application. Just as Helms (1992) has demonstrated that exotic materials or particular forms of workmanship are useful clues for identifying symboli- 
cally "charged" artifacts, the attributes of certain animals in faunal assemblages (for instance, identification of rare or dangerous taxa, etc.) recovered from suspected high-status contexts may be useful in evaluating the ways in which rank differences affected foodways variation in other archaeological contexts.

Acknowledgments. The National Science Foundation (Award 920658) and the University of Alabama supported the excavations on which this study is based. The University of Southern Mississippi provided laboratory space as well as support for the research described here. We gratefully acknowledge access to the Ornithology Skeletal Collection of the University of Michigan's Museum of Zoology, permitting identification of some of the rarer bird taxa and collections at the American Museum of Natural History and the Smithsonian Institution, which greatly facilitated the identification of bison from Moundville. Thanks to Elizabeth Reitz, director of the Georgia Museum of Natural History, for access to collections there. Special thanks are due the Principal Investigator, Vernon J. Knight, for his particular patience during the course of the analysis, and for his comments on an earlier version of this manuscript. We've also benefited from many discussions with Paul Welch and Margaret Scarry about Moundville archaeology and from Paul's comments on an earlier version of the paper. Francisco Melara kindly prepared the Spanish abstract. Finally, we appreciate the insightful comments of Christopher S. Peebles, Nancy M. White, and two anonymous reviewers, all of whom helped to clarify the presentation of our work.

\section{References Cited}

Anderson, David G.

1994 The Savannah River Chiefdoms: Political Change in the Late Prehistoric Southeast. University of Alabama Press, Tuscaloosa.

Astin, Robyn

1996 Mound M: Chronology and Function at Moundville. Unpublished Master's thesis, Department of Anthropology, University of Alabama, Tuscaloosa.

Blitz, John H.

1993a Ancient Chiefdoms of the Tombigbee. The University of Alabama Press, Tuscaloosa.

1993b Big Pots for Big Shots: Feasting and Storage in a Mississippian Community. American Antiquity 58:80-96.

Binford, Lewis R.

1978 Nunamiut Ethnoarchaeology. Academic Press, New York.

1984 Faunal Remains from Klasies River Mouth. Academic Press, Orlando.

Binford, Lewis R., and J. B. Bertram

1977 Bone Frequencies and Attritional Processes. In For Theory Building in Archaeology, edited by L. R. Binford, pp. 77-153. Academic Press, New York.

Bogan, Arthur E.

1980 A Comparison of Late Prehistoric Dallas and Overhill Cherokee Subsistence Strategies in the Little Tennessee River Valley. Unpublished Ph.D. Dissertation, Department of Anthropology, University of Tennessee, Knoxville.
Clarke, John A., and Michael Blake

1994 The Power of Prestige: Competitive Generosity and the Emergence of Rank Societies in Lowland Mesoamerica. In Factional Competition and Political Development in the New World, edited by E. M. Brumfiel and J. W. Fox, pp. 17-30. Cambridge University Press, Cambridge.

Chmurny, William W.

1973 The Ecology of the Middle-Mississippian Occupation of the American Bottom. Ph. D. Dissertation, University of Illinois, Champaign-Urbana. University Microfilms, Ann Arbor.

Dietler, Michael

1996 Feasts and Commensal Politics in the Political Economy: Food, Power and Status in Prehistoric Europe. In Food and the Status Quest: An Interdisciplinary Perspective, edited by Polly Wiessner and Wulf Shiefenhovel, pp. 87-126. Berghahn Books, Providence.

Dietler, Michael, and Brian Hayden

2001 Feasts: Archaeological and Ethnographic Perspectives on Food, Politics, and Power. Smithsonian Institution Press, Washington, D.C.

Galloway, Patricia

1989 The Southeastern Ceremonial Complex: Artifacts and Analysis. University of Nebraska Press, Lincoln.

Gibson, Jon L.

2000 The Ancient Mounds of Poverty Point, Place of Rings. University Press of Florida, Gainesville.

Hayden, Brian

1995 Pathways to Power: Principles for Creating Socioeconomic Inequalities. In Foundations of Social Inequality, edited by T. Douglas Price and Gary Feinman, pp. 15-86. Plenum Press, New York.

1996 Feasting in Prehistoric and Traditional Societies. In Food and the Status Quest: An Interdisciplinary Study, edited by Polly Wiessner and Wulf Schiefenhovel, pp. 127-147. Berghahn Books, Providence.

Helms, Mary

1992 Political Lords and Political Ideology in Southeastern Chiefdoms: Comments and Observations. In Lords of the Southeast: Social Inequality and the Native Elites of Southeastern North America, edited by Alex. W. Barker and Timothy. R. Pauketat, pp. 185-194. American Anthropological Association Archaeology Papers 3, Washington, D.C.

Holm, Mary A.

1997 Appendix A: Zooarchaeological Remains from Moundville I Phase Features at 1TU66 and 1TU768. In West Jefferson Community Organization in the Black Warrior Valley, Alabama, by C. M. Scarry and J. F. Scarry. Report of Investigations prepared for the National Geographic Society. Report on file, Research Laboratories in Anthropology, University of North Carolina, Chapel Hill.

Hudson, Charles

1976 The Southeastern Indians. University of Tennessee Press, Knoxville.

Jackson, H. Edwin

2002 An Analysis of Faunal Remains from 1TU66, Tuscaloosa County, Alabama. Report on File, Research Laboratories in Anthropology, University of North Carolina, Chapel Hill.

Jackson, H. Edwin, and Susan L. Scott

1992 Vertebrate Remains from Big Village. In Archaeology and Ethnohistory of the Omaha Indians: The Big Village Site, edited by John M. O'Shea and John Ludwickson, pp. 329-340. University of Nebraska Press, Omaha.

1995a Mississippian Homestead and Village Subsistence Organization: Contrasts in Large-Mammal Remains from 
Two Sites in the Tombigbee Valley. In Mississippian Communities and Households, edited by J. Daniel Rogers and Bruce D. Smith, pp. 181-200. University of Alabama Press, Tuscaloosa.

1995b The Faunal Record of the Southeastern Elite: The Implications of Economy, Social Relations, and Ideology. Southeastern Archaeology 14:103-119.

2002 Appendix E: Faunal Utilization by the Moundville Elite: Zooarchaeology of Mounds Q, G, E, F, and R. In Chronology and Use of Public Architecture at Moundville: Excavations in Mound Q, by Vernon J. Knight. Report submitted to the National Science Foundation, Award No. 9727709. Report on file, Department of Anthropology, University of Alabama, Tuscaloosa.

Johnson, Jay K., Susan L. Scott, James R. Atkinson, and Andrea Shea

1994 Late Protohistoric Settlement and Subsistence on the Black Prairie: Buffalo Hunting in Mississippi. North American Archaeologist 15:167-179.

Kelly, Lucretia S.

2001 A Case of Ritual Feasting at the Cahokia Site. In Feasts: Archaeological and Ethnographic Perspectives on Food, Politics, and Power, edited by M. Dietler and B. Hayden, pp. 334-367. Smithsonian Institution Press, Washington, D.C.

Kent, Susan

1989 Cross-cultural Perception of Farmers as Hunters and the Value of Meat. In Farmers as Hunters: The Implications of Sedentism, edited by Susan Kent, pp. 1-17. Cambridge University Press, Cambridge.

Knight, Vernon J.

1989 Certain Aboriginal Mounds at Moundville: 1937 Excavations in Mounds H-L. Paper presented at the 46th Annual Meeting of the Southeastern Archaeological Conference, Tampa.

1992 Preliminary Report on Excavations at Mound Q, Moundville. Paper presented at the 49th Annual Meeting of the Southeastern Archaeological Conference, Little Rock.

1995 Chronology and Use of Public Architecture at the Moundville Site: Excavations in Mounds R, F, G, and E. Second Interim Report to the National Science Foundation, Award No. 920658. Report on file, Department of Anthropology, University of Alabama, Tuscaloosa.

1998 Moundville as a Diagrammatic Ceremonial Center. In Archaeology of the Moundville Chiefdom, edited by Vernon J. Knight and Vincas Steponaitis, pp. 44-62. Smithsonian Institution Press, Washington, D.C.

2001a Characterizing Elite Midden Deposits at Moundville. Paper presented at the 66th Annual Meeting of the Society for American Archaeology, New Orleans.

2001b Feasting and the Emergence of Platform Mound Ceremonialism in Eastern North America. In Feasts: Archaeological and Ethnographic Perspectives on Food, Politics, and Power edited by Michael Dietler and Brian Hayden, pp. 311-333. Smithsonian Institution Press, Washington, D.C.

Knight, Vernon J., and Vincas P. Steponaitis

1998 A New History of Moundville. In Archaeology of the Moundville Chiefdom, edited by Vernon J. Knight and Vincas P. Steponaitis, pp. 1-25. Smithsonian Institution Press, Washington, D.C

Lorenz, Karl

1996 Small-scale Mississippian Community Organization in the Big Black River Valley of Mississippi. Southeastern Archaeology 15:145-171.
Lyman, R. Lee

1984 Bone Density and Differential Survivorship of Fossil Classes. Journal of Anthropological Archaeology 3:259-299.

1991 Taphonomic Problems with Archaeological Analyses of Animal Carcass Utilization and Transport. In Beamers, Bobwhites, and Blue-points, edited by James R. Purdue, William E. Klippel, and Bonnie W. Styles, pp. 125-138. Illinois State Museum Scientific Papers Vol. 23, and the University of Tennessee, Department of Anthropology Report of Investigations No. 52. Illinois State Museum, Springfield.

Madrigal, T. Craig, and Julie Zimmerman Holt

2002 White-Tailed Deer Meat and Marrow Return Rates and the Application to Eastern Woodlands Archaeology. American Antiquity 67:745-759.

Markin, Julie G.

1997 Elite Stoneworking and the Functions of Mounds at Moundville. Mississippi Archaeology 32:117-135.

Maxham, Mintcy D.

2000 Rural Communities in the Black Warrior Valley, Alabama: The Role of Commoners in the Creation of the Moundville ILandscape. American Antiquity 65:337-354.

Metcalf, Duncan, and Kevin T. Jones

1988 A Reconsideration of Animal Body Part Utility Indices. American Antiquity 53:486-504.

Michals, Lauren

1987 Faunal Remains. In The Mill Creek Site, 1TU265, Black Warrior River Valley, Alabama, edited by Tim S. Mistovich, 171-182. Report of Investigations 54. University of Alabama Office of Archaeological Research, Tuscaloosa.

1992 The Nature of Faunal Exploitation in Mississippian Societies. Paper presented at the 57th Annual Meeting of the Society for American Archaeology, Pittsburgh.

1997 The Oliver Site and Early Moundville I Phase Economic Organization. In Archaeology of the Moundville Chiefdom, edited by V. J. Knight and V. P. Steponaitis, pp. 167-182. Smithsonian Institution Press, Washington, D.C.

Muller, Jon

1997 Mississippian Political Economy. Plenum Press, New York.

Pauketat, Timothy R., Lucretia S. Kelly, Gayle J. Fritz, Neal H. Lopinot, Scott Elias, and Eve Hargrave

2002 The Residues of Feasting and Public Ritual at Early Cahokia. American Antiquity 67:257-279.

Peebles, Christopher S.

1971 Moundville and Surrounding sites: Some Structural Considerations of Mortuary Practices. In Approaches to the Social Dimension of Mortuary Practices, edited by James A. Brown, pp. 68-91. Memoir 15, Society for American Archaeology, Washington, D.C.

1978 Determinants of Settlement Size and Location in the Moundville Phase. In Mississippian Settlement Patterns, edited by Bruce D. Smith, pp 369-416. Academic Press, New York

1983 Moundville: Late Prehistoric Sociopolitical Organization in the Southeastern United States. In The Development of Political Organization in Native North America, edited by Elizabeth. Tooker, pp. 183-201. American Ethnological Society, Washington, D.C.

Peebles, Christopher S., and Susan M. Kus

1977 Some Archaeological Correlates of Ranked Societies. American Antiquity 42:421-448.

Peebles, Christopher S., and Margaret J. Schoeninger

1981 Notes on the Relationship between Social Status and 
Diet at Moundville. Southeastern Archaeological Conference Bulletin 24:96-97.

Potter, James M.

2000 Pots, Parties, and Politics: Communal Feasting in the American Southwest. American Antiquity 65:471-492.

Purdue, James R.

1983 Epiphyseal Closure in Whitetail Deer. Journal of Wildlife Management 47:1207-1213.

Rees, Mark A.

1997 Coercion, Tribute and Chiefly Authority: The Regional Development of Mississippian Political Authority. Southeastern Archaeology 16:113-133.

Ryba, Elizabeth A.

1995 Summit Architecture on Mound E at Moundville. Unpublished Master's thesis, Department of Anthropology, University of Alabama, Tuscaloosa.

Scarry, C. Margaret

1996 Archaeobotanical Analysis. In Chronology and Use of Public Architecture at the Moundville Site: Excavations in Mounds $R, E, F$, and $G$, edited by V. J. Knight. Second Interim Report to the National Science Foundation. Asward No. 920658. Report on file, Department of Anthropology, University of Alabama, Tuscaloosa.

Scarry, C. Margaret, and John. F. Scarry

1997 West Jefferson Community Organization in the Black Warrior Valley, Alabama. Report of Investigations prepared for the National Geographic Society. Research Laboratories in Anthropology, University of North Carolina, Chapel Hill.

Schambach, Frank F.

1993 Some New Interpretations of Spiroan Culture History. In Archaeology of North America: Papers in Honor of Stephen Williams, edited by James B. Stoltman, pp. 187-230. Archaeological Report No. 25, Mississippi Department of Archives and History, Jackson.

Schoeninger, Margaret J., and Mark R. Schurr

1998 Human Subsistence at Moundville: the Stable Isotope Data. In Archaeology of the Moundville Chiefdom, edited by Vernon J. Knight and Vincas P. Steponaitis, pp. 120-132. Smithsonian Institution Press, Washington, D.C.

Schorger, A. William

1966 The Wild Turkey. University of Oklahoma Press, Norman.

Scott, Susan L.

1982 Yarborough Site Faunal Remains. In Archaeological Investigations at the Yarborough Site (22CL814), Clay County, Mississippi, edited by Carlos Solis and Richard Walling, pp. 140-152. Report of Investigation 30, Office of Archaeological Research, University of Alabama, Tuscaloosa.

1983 Analysis, Synthesis, and Interpretation of Faunal Remains from the Lubbub Creek Archaeological Locality. In Prehistoric Agricultural Communities in West Central Alabama, edited by Christopher S. Peebles, pp. 272-290. Report submitted to the U.S. Army Corps of Engineers, Mobile District.

Scott, Susan L., and H. Edwin Jackson

1998 Early Caddo Ritual and Patterns of Animal Use: Analysis of Faunal Remains from the Crenshaw Site (3MI6), Southwestern Arkansas. The Arkansas Archeologist 37:1-38.

Scott, Susan L., and Michael Tuma

1998 Analysis of Faunal Remains from ImmoKakina'Fa'. Unpublished report on file, Cobb Institute of Archaeology, Mississippi State University, Starkville.

Smith, Bruce D.
1975 Middle Mississippian Exploitation of Animal Populations. Anthropological Papers No. 57, University of Michigan Museum of Anthropology, Ann Arbor.

Smith, Marvin T., Vernon J. Knight, J. B Smith, and K. R. Turner 1993 The Milner Village, a Mid $17^{\text {th }}$ Century Site near Gadsden, Alabama. In Archaeological Survey and Excavations in the Coosa River Valley, Alabama, edited by V. J. Knight, pp. 49-70. Alabama Museum of Natural History Bulletin 15, Tuscaloosa.

Speth, John D., and Susan L. Scott

1989 Horticulture and Large-Mammal Hunting: The Role of Resource Depletion and the Constraints on Time and Labor. In Farmers as Hunters: The Implications of Sedentism, edited by Susan Kent, pp. 71-79. Cambridge University Press, Cambridge.

Steponaitis, Vincas P.

1998 Population Trends at Moundville. In Archaeology of the Moundville Chiefdom, edited by Vernon J. Knight and Vincas P. Steponaitis, pp. 26-43. Smithsonian Institution Press, Washington, D.C.

Swanton, John R.

1911 The Indians of the Lower Mississippi Valley. Bureau of American Ethnology Bulletin 43. U.S. Government Printing Office, Washington, D.C.

Taft, Kristi E.

1996 Functionally Relevant Classes of Pottery at Moundville. Unpublished Master's thesis, Department of Anthropology, University of Alabama.

van der Schalie, Henry, and Paul Parmalee

1960 Animal Remains from the Etowah Site, Mound C, Bartow County, Georgia. The Florida Anthropologist 13:37-54.

Van Derwarker, Amber M.

1999 Feasting and Status at the Toqua Site. Southeastern Archaeology 18:24-34.

Walthall, John S.

1980 Prehistoric Indians of the Southeast: Archaeology of Alabama and the Middle South. University of Alabama Press, Tuscaloosa.

Welch, Paul D.

1991 Moundville's Economy. University of Alabama Press, Tuscaloosa.

1998 Outlying Sites within the Moundville Chiefdom. In Archaeology of the Moundville Chiefdom, edited by Vernon J. Knight and Vincas P. Steponaitis, pp. 133-166. Smithsonian Institution Press, Washington, D.C.

Welch, Paul D., and C. Margaret Scarry

1995 Status-Related Variation in Foodways in the Moundville Chiefdom. American Antiquity 60:397-419.

Wiessner Polly, and Wulf Schiefenhovel (editors)

1996 Food and the Status Quest: An Interdisciplinary Study. Berghahn Books, Providence.

Wilson, Gregory D.

2001 Small Celt, Big Celt, Old Celt, New Celt: The Early Mississippian Greenstone Tool Industry at Moundville. Southeastern Archaeology 20:118-127.

Zeder, Melinda A.

1996 Zooarchaeological Approaches to Complexity: A View from the Old World. Paper presented at the 53rd Annual Meeting of the Southeastern Archaeological Conference, Birmingham.

\section{Notes}

1. Fox is nonetheless interesting, appearing in southeastern representational art at least as early as the Late Archaic 
Poverty Point period in the Lower Mississippi Valley and playing a role in Choctaw conceptions of supernatural beings (e.g., Gibson 2000:191).

2. Other food utility indices have been developed, building on Binford's analysis, for instance Metcalfe and Jones (1988). Recently, Madrigal and Holt (2002) reported meat and marrow values for whitetail deer carcass portions, unfortunately after the present analysis was completed. Metcalfe and Jones' (1988) analysis reports little change in the rank ordering of anatomical portions; thus, we are comfortable staying with Binford's MGUI, at least for the time being.

Received August 26, 2002; Revised December 17, 2002, Accepted December 17, 2002. 